\title{
Practices on a Literacy Class for Young and Adults Education in Brazil
}

\section{Ariádene de Almeida Matos Nascimento, Dinani Gomes Amorim, Cosme Batista dos Santos, Ricardo José Rocha Amorim}

State University of Bahia, Juazeiro, Brazil

Email: ariadened@outlook.com, damorim@uneb.br, cbsantos@uneb.br, amorim.ricardo@gmail.com

How to cite this paper: de Almeida Matos Nascimento, A., Amorim, D. G., dos Santos, C. B., \& Amorim, R. J. R. (2019). Practices on a Literacy Class for Young and Adults Education in Brazil. Creative Education, 10, 901-912.

https://doi.org/10.4236/ce.2019.105067

Received: April 7, 2019

Accepted: May 13, 2019

Published: May 16, 2019

Copyright $\odot 2019$ by author(s) and Scientific Research Publishing Inc. This work is licensed under the Creative Commons Attribution International License (CC BY 4.0).

http://creativecommons.org/licenses/by/4.0/

\begin{abstract}
The main objective of this work is to dialogue with the different works of literature in a social perspective of the practices of reading and writing. It seeks to achieve an education oriented to transculturality taking into account the different cultural and social aspects of society. In this sense, conceptions concerning literacy events and practices are highlighted through a contextualization. Then, a description is made from the observation of the environment and its participants, plus interpretations obtained from the data collected. This research is based initially on a bibliographical review, based on the theoretical contribution of the use of the New Letters Studies and follows a qualitative, descriptive, ethnographic methodological approach, through field research, using instruments such as participant observation, semi-structured interviews, and questionnaires for data collection. Finally, in the discussion, we considered the analysis of the results obtained and, in the final considerations, some recommendations about the practice of literacy and education based on multiculturalism are presented.
\end{abstract}

\section{Keywords}

Literature, Event, Education, Interculturality

\section{Introduction}

Man as a being who lives in society, always seeking to establish and expand his network of relationships, finds in social practices supports for effective participation and interaction with the world, contributing to the realization of an effective communicative process, especially when it comes to the reading and writing practices. Thus, it is not enough just to know how to decode, read without assigning sense and transcribe, or make use of writing as a skill, technique, with an 
end in itself. It is essential to develop reading and writing skills as social practices that involve values, cultures, ideas, and the subjects' contexts (Soares, 2017: pp. 70-74), making them agents with a recognized identity and ability to find solutions to the problems of daily life, playing the role of critical citizen.

Faced with this scenario, reading and writing without attribution of meaning, devoid of context, cannot account for the main essence: interaction. Thus, it becomes necessary to enter the ideological literacy as a more comprehensive proposal that can play an important role and respond to the expectations of the current social and educational panorama, or rather, emphasizing literacy practices in line with the proposal of an education based on the valuation of different cultures, on the various ways of articulating with knowledge in consonance with the daily life of individuals (de Rezende, 2016: p. 98). With this, in the Education of Young and Adults-EYA, there is the possibility of more meaningful and coherent experience with the local community and the globalized world. In Brazil, the EYA gained emphasis from the 1990s, when it was recognized as a level of basic education in accordance with the 1996 Guidelines and Bases Law (Brazil, 1996). This modality has particularly contributed to the training of people from young people, adults and the elderly, who are in a vulnerable situation in relation to their stay in the regular education level and who need to regularize their educational level in order to complete important cycles in the process of teaching and learning (Haddad \& di Pierro, 2000; Dias et al., 2013).

From this perspective, a crucial question arises: Under which perspective are literacy practices considered in EYA? Do the practices of writing and reading have taken into account their context of production, cultural and social aspects? And teachers have prioritized what literacy in their pedagogical practice?

In the face of these questions, this paper aims to analyze the conceptions of literacy and the evidence of the different literacy practices in the classroom, observing if they are considered in a social perspective, especially when referring to the research group of EYA. In addition, seeking to clarify about literacy events as more evident actions linked to literacy practices, as addressed by Castanheira et al. (2007) "refers to the most observable elements of activities involving reading and writing".

Thus, the importance of investigating EYA class literacy practices lies in the fact that the school needs to make room for social reading and writing practices, taking into account the different modes of production, situating "literacy practices in the context of power and ideology" (Street, 2007: p. 465), not only privileging literacy as a neutral skill, a technique in which events go unnoticed and are not considered propulsive springs, indicators of revelation (de Rezende, 2016: p. 99).

In addition, for believing that EYA is a teaching modality that requires more attention from teachers so that students have more efficient support and stay in school, seeking knowledge, enabling the interaction process, giving meaning to their experiences, complete in less time, qualifying for better opportunities in the job market. In addition, for the importance of discovering and delineating which 
practices of literacies are being considered in the pedagogical practice of the teacher of the EYA.

Thus, it is possible to believe in a significant and effective change in the educational process and, more specifically, in the formation of the individual as a citizen aware of his social role, appropriating social practices in relation to the use of reading and writing since the main (Santos, 2008: p. 85) is willing to adopt a methodology based on reflection, a dialogical relationship in an intercultural perspective.

Therefore, in order to delineate this article in an objective, coherent and logical way, it will present a brief history regarding the conceptions of literacy, as well as it's unfolding, besides the methodological path, the results obtained and discussion from the field research followed of the final considerations.

\section{Literacy in Focus}

According to Soares (2002) from a pedagogical perspective, literacy has appeared here in Brazil for at least three decades and has been extended in the area of languages as a way of responding to the amplitude of what occurred in the teaching and learning of written language, due to the development in the social, economic and political sphere. In this perspective, literacy appears to account for the demands that go beyond the comprehension of reading and writing as technical skills, with an end in itself, without taking into account the context of production, the results of the interaction process. As some authors claim, literacy involves more than individual processes of reading and writing-it also involves shared communicative contexts. And from these, what is meant by literate actions is locally defined (Castanheira et al., 2007: p. 8).

However, despite this interest in giving new coverage to social practices of reading and writing, the school still continues to focus literacy as a skill, or rather, to acquire an individual competence without interference from the social environment. Thus, the practices of reading and writing compete for the privilege of only one type of literacy, characterized as dominant, unilateral, as a result of a finished production itself, as Kleiman (1995: p. 20) states "it can be affirmed that the school, the most important of the agencies of literacy, is concerned not with literacy, social practice, but with only one type of literacy practice, that is, the process of acquisition of codes", this devoid of the social context for being interpreted and meaningful.

In this way, literacy loses its highest essence in the social environment as far as writing is concerned, in opposition to the ideological model that emphasizes the importance of the plurality of literacy practices, considering social and cultural aspects and the own meanings that writing acquires in different contexts of acquisition, according (Kleiman, 1995). Thus, in this work, it becomes fundamental to speak from the perspective of the "ideological model of literacy, which recognizes a multiplicity of works of literature; that the meaning and uses of literacy practices are related to specific cultural contexts" (Street, 2007: p. 466), and also adds the social aspects of everyday life to which subjects are exposed. This 
model makes it possible to analyze literacy practices, considering cultural and social elements for the practice of writing in various contexts through interaction, appreciation of local elements, interconnecting with other extra locals, promoting a more meaningful writing practice, coherent approach, which aims not only at the domain of a particular skill, such as coding and decoding symbols, but rather at competencies, which will serve as a support to act actively in a critical way, making it possible to better understand and interact with the world in which the subjects are inserted.

Thus, it is necessary to overcome the unilateral view that only one type of literacy is the main alternative to reach social ascension, otherwise it will be prioritizing one form to the other, that is, choosing a single form as standard, giving it a dominant and indispensable character to facilitate access to the different social spheres. To do so, to follow a more viable, less traditional way, it becomes impossible to make reading and writing practices viable, as activities interconnected with the social context of the community, recognizing the cultural, political, historical and ideological aspects relevant to the reality of the subjects. For this, the school needs to offer opportunity and experience of literacy in its plurality, emphasizing fundamental aspects of culture and society, as well as valuing the different intellectual and formal practices that should compose the universe of literate practices. Thus, it is essential to focus on an education in which it favors a pedagogical practice centered on interculturality, which makes possible the coexistence between different cultures and the full interaction between the knowledge.

\section{Practices and Literacies Events}

Facing the scenario in which literacy is considered as plural and situated social practices that should involve and value the varied social and cultural contexts, it is also possible to highlight the literacy practices and events that constitute important concepts that guarantee meanings to social practices (Barton, 1996), Barton and Hamilton (1998), Street $(2007,2012,2014)$ and others.

With this, it is essential to emphasize social literacy as a way of valuing different modes of interaction, in which literacy practices and events, from a sociocultural perspective, are highlighted as peculiarities of the literacy phenomenon and, although they are part of the same scenario, are closely related, as clarified by Soares (2004), and serve as the basis for researchers to analyze the literacy of various social groups, also have some different characteristics. Thus, events are more noticeable in concrete reality and appropriate writing to establish the process of interaction, as Heath (1982 apud Street, 2012: p. 73) explains in stating that "literacy events" refer to "any at which point a piece of writing is essential to the nature of the participants' interactions and their interpretive processes". In this way, the literacy event is based on the use of writing for the promotion of interactive moments and that results in important assimilation of the communication process. In a similar way, Barton (1994 apud Santos, 2011) clarifies that the literacy event occurs when a person uses reading to understand graphical 
signs, that is, writing. From this process, the conception of events originates that can serve as a basis for understanding particular situations in which writing is contemplated and perceived in a concrete way (Barton \& Hamilton, 1998).

Literacy practices, on the other hand, receive a different conception, in order to reach a higher degree of abstraction, in a broader perspective, although it also prevails through interaction, as Street (2014: p. 18) states: "the concept of 'literacy practices' puts it at a higher level of abstraction and refers equally to behavior and social and cultural conceptualizations that give meaning to the uses of reading and/or writing". With this, it is possible to clarify that literacy practices occur at all times, within a broader field in which reading is carried out, and especially writing, in a special dynamic of social relations.

In view of this, literacy practices encompass not only literacy events, but also everyday activities involving literacy (Street \& Castanheira, n.d.; Street, 2014) and, further reinforcing this idea, the following authors affirm that events are situations that from the practices and are outlined from them (Barton \& Hamilton, 1998). Thus, it is possible to affirm that literacy events and practices integrate as essential actions in the same scenario, favoring the process of interaction and practice of social literacy.

Moreover, according to Kleiman (1995: p. 40), literacy events refer to "situations where writing is an essential part of making sense of the situation, both in relation to the interaction between participants and in relation to processes and strategies". With this, it can be affirmed that from the moment that writing is part of the process of mediation in a situation of social interaction, it means that it is a literacy event. In addition, these events constitute the threshold to reach the domain of practices still latent and evidence something that is perceptible according to Barton and Hamilton (1998). That is, these episodes can make it possible to unlock potentialities that were implicit and thus, compete for other developments.

Given this, it is correct to affirm that several people in different spaces, involving different written texts, since people experience different interests in daily life and use different strategies to perform their interpretations and interact with the world, can experience both practices and events. Highlighting that, the ideal is the valorization, the respect to the different cultural and social aspects that can be considered with fundamental for a promising education and that corroborate effectively for the formation of the citizen.

\section{Methodology}

This research was carried out at the State School Viegas, located at Rua Marechal Bittencourt in Alagoinhas, Bahia, Brazil. This school was chosen considering that it involves the three modalities of education, comprising elementary education II, high school, both in the daytime period and EYA, in the night shift.

Also, this school counts on 53 professors, all with graduation degree (called Licenciatura in Brazil), and attends to about 1400 students, distributed in the 
three daily shifts. The target audience refers to one of several classes, class D, axis VI, EYA, in the night shift, more specifically, to the ten students who participated in the three moments in which they were requested. The interest was concentrated in room 10, believing that it presents relevant characteristics in relation to the object of study. This class consists of 35 students, comprising adults aged 18 to 46 years. Therefore, it is a mixed group, involving young people and adults, who attend the unit with the aim of improving their knowledge, their possibility of participation and growing integration in society.

Thus, with the locus and the target audience defined, the methodological path adopted to carry out the research is highlighted: a methodological approach predominantly qualitative, since the main purpose of this research is the understanding of "a phenomenon can be better understood in the context in which it occurs and of which it is a party, should be analyzed from a integrated" (Godoy, 1995: p. 21). However, without disregarding the quantitative aspect at times. As for the objective, it refers to a descriptive research, supported by induction, of an ethnographic nature, since the focus is given to the process of interaction between the subjects, and "concern is in meaning with the way people see themselves, their experiences, and the world around them", according André (1995: p. 29).

Concerning the procedures, a bibliographic review was initially based on the theoretical studies and interpretations of ideas contained in the articles, reviews and books of important authors that approach the theme under study, establishing a relationship with the data collected during field research. The latter was later carried out with the purpose of contextualizing and enriching the interpretations obtained from the analysis of the information collected.

In this way, participant observation, interviews, and semi-structured questionnaires were used as data collection instruments because they represent better options for obtaining information, listening and giving meanings to the subjects' speeches, making descriptions of the reality experienced by the respondents. To ensure the records, the field diary, the audio recording was used since the direction of the College did not authorize the use of a record of images. Thus, based on the relationship established between the concepts learned from the bibliographic research and the results obtained with the data collection in the field research, it was possible to carry out the analysis and interpretation of the data in an organized and systematic way to obtain a more reliable result possible.

At the first contact of the researcher, the teacher and the students showed calm and solicitous, interacted during the class, participating in the activities. During the observations, it was noticed that the responsible teacher initially involved the group through informal conversation. After that moment, he presented the text copied on the board, requested the reading and soon afterward, began the oral discussion, involving the textual theme, in which the majority of the class participated, giving an opinion, relating to personal life. He also studied the vocabulary and then applied the objective and subjective questions that should be noted and answered in the notebook. 
It was also observed that some complained when, since most of the questions were open, but, lastly, almost the entire room participated in the practice of literacy, deserving prominence a literacy event in relation to a student, who read the text exposed on the chalkboard, produced a poem in response to an issue and voluntarily declaimed it into the room. The teacher intervened the whole process, helping to understand some words and what each question demanded since many commented that they had not understood some questions.

In a second opportunity, where the class was already more familiar with the researcher's presence, a semi-open questionnaire with ten questions was explained and applied to those students who proposed to collaborate with the research. Then the teacher continued the lesson, placing a small sound, which connected to the cell phone played a song: Caboclo dreamer of Maciel Melo, played by the singer Flávio José, then presented the lyrics in writing and then began the discussion about the related to what was worked on in the previous class. The students actively participated in the comments, presented examples referring to their daily lives.

Following the teacher, he read the biography of singer Flávio José, explained what the biographical text is, wrote down the characteristics on the board and requested the production of an autobiographical text. Once again, the practice of literacy is visible, in which the student is offered writing that involves their context and serves to expose their condition of being in the world, taking into account aspects of their community, culture, and place in society.

Already in a third moment, the selection of ten students to participate in the interview was carried out. Of these, five volunteered and the others were chosen for spontaneity in the classroom. During the interview, these students answered five questions regarding the meaning of reading and writing in their daily lives, relating to school activities.

\section{Results}

After applying the research instruments, data collection, analysis and interpretations, it became clear that for the participants the practice of reading and writing require knowledge and deepening of ideas, so students prefer informal conversation. However, students recognize the importance and necessity of these two practices as a way to enable interaction to improve learning and enable intellectual development. Thus, when analyzing the information obtained from the subjects' experiences, the following results were obtained (Figure 1).

Regarding the type of reading, both in the questionnaires and in the interviews, the balance prevailed, most stated that reading for fun and the rest for information. When questioned about the practice of reading and writing in school, the majority reacted positively, affirming that reading and writing are handled in a contextualized way.

In relation to writing, most said that they practice daily, especially at school, others said they use it at home and at work. This group prefers literary writing, 


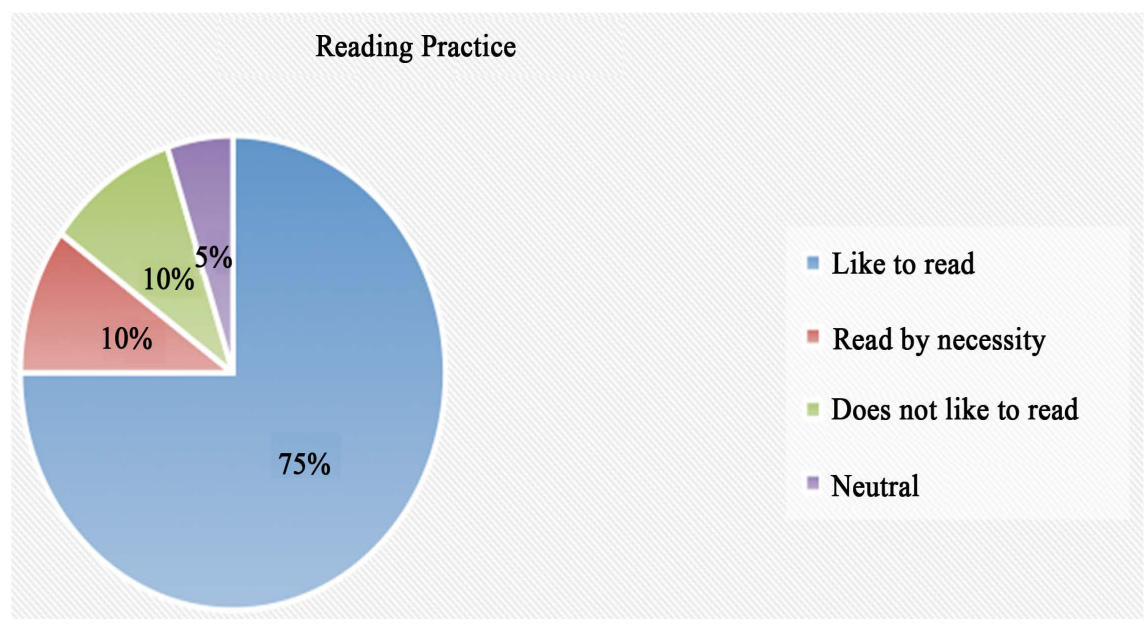

Figure 1. The practice of reading from the students. Source: Authors.

with few options for informative. The respondents consider that they dominate the writing and when carrying out the analysis of the data, the following result was obtained as shown in the graph (Figure 2).

Although only a small portion of the class confirms that they write very well and most have a reasonable mastery of writing, these students do not view writing as an obstacle. In this context, we highlight as evidences of the practices and events of literacy during the classes of Portuguese Language in class $\mathrm{D}$, of the course of Education for Young and Adults-EYA of the College in question:

- Those students make use of reading and writing, generally, taking into account the teacher's proposals that use a mix between traditional pedagogical practices with contemporary nuances.

- During the period of coexistence, it was possible to notice that the classes usually consist of informal conversations, presentation of texts, followed by reading and then, of writing practice, be it a text, a summary or questions related to the subject studied. This last action is quite visible, especially noting what the teacher wrote on the board, but it is not a written one, the one that represents a construction from the abstracted knowledge throughout life, involving the context of the individual, seems artificial.

- In a global interpretation, there is a greater ease in oral activities, common to students' daily life, in which they became involved without concern of the organization of speech.

- In the area of reading, few were interested and used various excuses not to participate in the activities. Thus, it is possible to clarify that during the observations, in relation to the practice of reading there was not registered an expressive involvement.

- The teacher, when using different strategies, realized that reading and writing are a constant part of everyday classroom discipline, and thus, by mixing a more contemporary pedagogical proposal, at times the activities are interfered with by a practice centered on proposals of formality. 


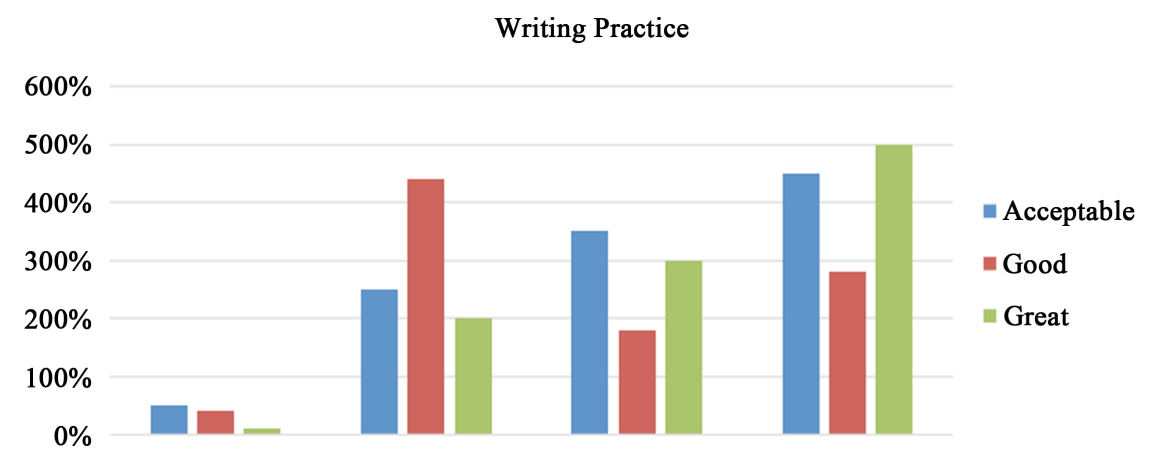

Figure 2. The writing practice according the students. Source: Authors.

- In the subjective questions that needed to be contextualized with other realities, it was noticed that the majority presented a greater degree of difficulty in the use of writing, being obvious setbacks to organize the statements, preferring to give short and superficial answers, sometimes imprecise and a minority, could not respond.

Thus, it is correct to say that students are interested, read passively and think, produce texts, although some have difficulties to formally organize the text, on the other hand, they can establish the process of interaction in a dynamic way. Especially when the activity involves aspects of their experience, such as, for example, in the production of autobiography, greater participation and better performance in productions were obtained. For those researched, the activities of reading and writing are fundamental, necessary for the understanding of different situations in the daily life and it serves so that they are able to participate more actively of the social life. Although many acknowledge that they do not master these practices, as they would like, perhaps, formally, they use them to establish relationships, solve problems, and to achieve their goals, so they practice it in a socially way. These are possibilities that effectively contribute to the process of interaction between the individual and the world. According to the interviewees, these reading and writing practices are still more important because they involve all the disciplines and are present in almost everything, so they cannot be left in the background, they must be valued, strengthened and worked increasingly, not only for evaluation but mainly to improve communication, the relationship between individuals.

Finally, these observations do not exhaust this process and do not represent the total result of this research, since when it refers to positioning in relation to the text that establishes a connection with the experience of these students, many write and participate actively, guaranteeing writing as a social practice, in which its use has a meaning, fundamental aspect and of relevance in this work.

\section{Conclusion}

Therefore, aiming to analyze the literacy and its conceptions, in addition to the evidence of the various practices of literacy in an EYA class, characterized by the presence of students who no longer have access to school at the conventional age 
for different reasons and now can resume their studies and conclude in less time, if it qualifies, becomes essential; investing more and more in an education that excels in intercultural communication, valuing differences, integrating them as a way to favor culture, society and individuals in a process of interaction continuous and dynamic.

Thus, at the end of this article, it is evident that studies on literacy have contributed effectively to a more accurate look of the teacher regarding reading and writing practices not only in the school environment, but also in daily life, recognizing the need to consider and practice literacy practices in the most ideal sense, undertaking the social and cultural character that favors the integration, understanding, interpretation of ideas and integral participation in the world of interaction.

Thus, it is necessary to continue disseminating literacy practices, in order to really achieve the desired level that is the viability of social practices of reading and writing in an efficient way, capable of generating significant changes in the interactions between the subjects involved in the process of production, as well as being attentive to literacy events that can signal potentialities within the school environment.

In this context, the willingness and desire of the respondents to learn, experience experiences and exercise their skills in the best possible way became visible. Hence it is important to reinforce the school's need to provide the contact, information, and guidance necessary for the practice of literacy within and outside the school context so that these people have the right to participate and meet social demands.

It is known that there is still an immense gap between the ideal and the real, but it is fundamental to follow this perspective of facing the literacy, or rather, social literacy, valuing the processes of interaction and communication, enabling an education of a cross-cultural nature, as to overcome the emblematic traditional characteristics that are inoperative of an educational system that has always privileged the interests of a ruling class, disregarding the context of formation of our population and the interests of a discriminated majority, which has been discredited throughout history, always marked by the condition acceptance of what is imposed on it.

For this change of attitude, it is indispensable of the effective performance of the teacher as a mediator, who always seeks strategies to deal with the differentiated clientele both in relation to knowledge and interests, and is effectively always willing to intervene to reach the goal which is intended to be an education with more innovative, or rather, renovating characteristics, giving space for transculturality, as a way of promoting a democratic education, in which the interests of various cultures are prevailed through integration, in a horizontal and synergistic relationship. In this context, diversity is contemplated and enriches the process of interaction, opening space for a dynamic, prosperous and effective coexistence regarding understanding, respect and value to the other. 


\section{Conflicts of Interest}

The authors declare no conflicts of interest regarding the publication of this paper.

\section{References}

André, M. (1995). Etnografia da prática escolar. São Paulo: Papirus.

Barton, D. (1996). Family Literacy Programmes and Home Literacy Practices. In D. Baker, J. Clay, \& C. Fox (Eds.), Challenging Ways of Knowing: In English, Mathematics and Science (p. 52). Hove: Psychology Press.

Barton, D., \& Hamilton, M. (1998). Local Literacy: Reading and Writting in One Community. Londres: Routledge.

Brasil (1996). Lei 9.394, de 20 de Dezembro de 1996. Lei de Diretrizes e Bases da Educação Nacional. http://www.planalto.gov.br/ccivil_03/leis/19394.htm

Castanheira, M. L., Dixon, C. N., \& Green, J. L. (2007). Práticas de letramento em sala de aula: Uma análise de ações letradas como construção social. Revista Portuguesa de Educação, 20, 7-38. http://www.scielo.mec.pt/pdf/rpe/v20n2/v20n2a02.pdf

Dias, D. S. F., de Deus, M. M. M., \& Ireland, T. D. (2013). A contribuição do uso de dispositivos móveis para um currículo voltado a uma educação transformadora na EJA. Revista Espaço do Currículo, 6, 280-291.

Godoy, A. S. (1995). Pesquisa qualitativa: Tipos fundamentais. Revista de Administração de empresas, 35, 20-29. http://www.scielo.br/pdf/rae/v35n3/a04v35n3 https://doi.org/10.1590/S0034-75901995000300004

Haddad, S., \& di Pierro, M. C. (2000). Escolarização de jovens e adultos. Revista Brasileira de Educação, 14, 108-130. http://www.scielo.br/pdf/rbedu/n14/n14a07.pdf

Kleiman, A. B. (1995). Modelos de letramento e as práticas de alfabetização na escola. In A. B. Kleiman (Ed.), Os Significados do Letramento: Uma Nova Perspectiva sobre a Prática Social da Escrita (pp. 15-21). Campinas: Mercado de Letras.

de Rezende, M. V. (2016). O conceito de letramento digital e suas implicações tecnológicas. Texto Livre: Linguagens e Tecnologias, 9, 94-99. https://doi.org/10.17851/1983-3652.9.1.94-107

Santos, C. B. (2008). Letramento e comunicação intercultural: O ensino e a formação do professor alfabetizador. In E. Mendes, \& M. L. S. Castro (Eds.), Saberes em português: Ensino e formação docente (pp. 79-95). Campinas: Pontes Editores.

Santos, R. L. (2011). Práticas e eventos de letramentos: Um estudo sobre os usos sociais da escrita de jovens de meios populares. Dissertação (Mestrado em Educação), Recife: Universidade Federal de Pernambuco, Centro de Educação.

Soares, M. (2002). Novas práticas de leitura e escrita: Letramento na cibercultura. Educação \& Sociedade Campinas, 23, 143-160. http://www.scielo.br/pdf/es/v23n81/13935 https://doi.org/10.1590/S0101-73302002008100008

Soares, M. (2004). Alfabetização e letramento: Caminhos e descaminhos. Revista Pátio, 29, 19-22.

Soares, M. (2017). Letramento: Um tema em três gêneros ( $3^{\mathrm{a}}$ ed.). Belo Horizonte: MG. Autêntica Editora.

Street, B. V. (2007). Perspectivas interculturais sobre o letramento. https://www.revistas.usp.br/flp/article/viewFile/59767/62876

Street, B. V. (2012). Eventos de letramento e práticas de letramento: Teoria e prática nos 
Novos Estudos do Letramento. In: I. Magalhães (Ed.), Discursos e práticas de letramento: Pesquisa etnográfica e formação de professors (69-92). Campinas: Mercado de Letras.

Street, B. V. (2014). Letramentos sociais: Abordagens críticas do letramento no desenvoIvimento, na etnografia e na educação. São Paulo: Parábola Editorial.

Street, V. B., \& Castanheira, M. L. (n.d.). Práticas e eventos de letramento.

http://ceale.fae.ufmg.br/app/webroot/glossarioceale/verbetes/praticas-e-eventos-de-letr amento 